\title{
IMPLANTATION OF A PLANT SCREENING AND COMPOSTING OF GARBAGE IN THE CITY OF MACAÉ
}

\author{
Marcelo Vizeu Dias \\ Marcos Antonio Cruz Moreira
}

\begin{abstract}
A growing waste generation and the need for final disposal is a major environmental concern in society today. The city of Macaé, due population growth caused by oil extraction and production pole in its region, has generated more waste than expected in recent studies taken for the implementation of the new landfill in the municipality. Deploying a sorting and composting plant would ease the burden of waste disposal on landfill, increasing its useful life, and unleashing the potential that the organic load, that forms much of the waste, can offer.
\end{abstract}

Keywords: Solid Waste, Composting and Screening Plant

\section{INTRODUCTION}

A growing generation of waste and the need for final disposal is a major environmental concern in society today. The discharge of garbage in cities around the world has always represented serious problem to public health and environment. Urban areas Deposits for centuries dealt without due care, have always been associated with disease widespread, either directly via people and animals coexistence in these places, either through contamination of water sources, soil and food (JAMES, 1997).

One way of attacking the problem would be to reduce the volume of waste generated. This reduction can be achieved through two pathways that complement each other. The first involves changing patterns of production and consumption, which can be regarded as the real solution to minimize the problem at its roots. However, this is a more utopian and long term goal. It involves deep cultural, economical and social changes. The second involves additional measures to be taken immediately, and helps to reduce the volume of disposed solid waste. These measures are those that act to reduce the huge under-utilizing the potential of municipal waste, either through recycling, composting, direct reuse or as energy production.

Among the alternative final destination for the waste generated, we can highlight: landfills, reuse, recycling, incineration and composting. However, in Brazil, much of generated waste is not collected, and from collected part, most are inadequately prepared. According to published studies, the best way to treat organic waste, comprising up to about $65 \%$ of total municipal generated waste (PEREIRA NETO, 1998) is to transform it into organic fertilizer.

The city of Macaé, due to population growth, caused by the installation of oil extraction and production pole in the region, has generated much more waste than expected in recent studies taken for the implementation of the new landfill in the municipality. The difference in the estimated waste generated by the RAS to the new landfill is 89 tons. These additional 89 tons will decrease the useful life of the landfill and can cause difficult remediation problems. The implementation of a sorting and composting plant would ease the burden of waste sent to landfill, increasing its useful life, and the profit potential of the organic load, which forms much of the waste, can offer.

\section{LITERATURE REVIEW}

\subsection{DEFINITION OF SOLID WASTE (MSW)}

The definition of solid waste, under the Standard NBR 10004 (ABNT, 2004) is as follows:

\footnotetext{
"Waste in solid and semi-solid, that result from activities of industrial, domestic, hospital, commercial, agricultural, services and sweeping. In-
} 
cluded in this definition the mud from water treatment systems, those generated in equipment and facilities for pollution control, and certain liquids whose characteristics make it infeasible its launch in public sewers or water bodies, or to require that solutions are technically and economically feasible given the best available technology."

Solid waste receives different ratings according to their origin, aggressiveness, purpose, chemical composition, among others. One of the major classifications of solid waste is given by ABNT, 2004 which divides the solid waste:

- Class I (hazardous): They have potential risk to public health and the environment. Display one or more characteristics of ignitability, corrosivity, reactivity, toxicity and pathogenicity;

- Class II (non-hazardous):

- Class IIA (non-inert): Are those who do not fit the classifications of waste class I or IIB. May exhibit properties such as biodegradability, combustibility and water solubility;

- Class IIB (inert). Any waste that has no constituents solubilized to concentrations above the drinking water standards, except for appearance, color, turbidity, hardness and flavor.

The Law 230 of 1991 establishing the National Policy on solid waste, classifies it as follows:

\section{I - AS TO THE ORIGIN:}

a) Municipal Solid Waste: solid waste generated by households, households, businesses, service providers and the public services from street cleaning and solid waste management, which by its nature or composition have the same characteristics as generated in households;

b) Industrial Solid Waste: solid waste from production processes and industrial facilities, as well as those generated in public sanitation;

c) Solid Waste from Health Services: solid waste from health services, as defined by the Ministry of Health in the relevant technical regulations; d) Rural Solid Waste: solid waste originating from agricultural activities, as well as those generated by inputs used in their activities, and

e) Special and Differentiated Solid Waste: those which by their size, degree of dangerousness, degradability or other specifics, require special or different procedures for handling and disposal, considering the negative impacts and risks to health and the environment.

\section{II - AS TO THE PURPOSE:}

a) solids reverse: solid waste recoverable by means of reverse logistics, targeting treatment and reuse in new products in form of inputs in its cycle or other productive cycles, and

b) waste: solid waste that, after having exhausted all possibilities for treatment and recovery process technology affordable and available, show no other possibility than landfill disposal.

A more specific classification for solid waste (MSW), besides the previously mentioned in the draft Act 203 of 1991, is given by FEEMA (FEEMA, 1994), which deals with MSW as

\footnotetext{
"Solid and semi-solids generated in a crowded urban (residential, commercial, public parks, industries, hospitals, etc..), Except for industrial waste from processes and treatment, septic hospital and those coming from ports and airports."
}

\subsection{MSW GENERATION}

The generation of MSW is dependent on cultural factors, consumption habits, purchasing power, climatic factors, educational level and age and gender characteristics of population groups, being affected also by changes in the economy, and seasonal climatic aspects, regional influences, migration and tourism (Neto, 2006).

Quantifying practice is based on production per capita index called garbage, which represents the amount of solid waste generated per capita in a given time, usually expressed as $\mathrm{kg} /$ hab.day.

In Latin America and the Caribbean, the generation of municipal solid waste varies from $0.5 \mathrm{a} 1,2 \mathrm{~kg} /$ hab.day, and the regional average of $0.92 \mathrm{~kg} /$ hab.day. In metropolitan areas and cities with more than 2 million people the average is $0.97 \mathrm{~kg} /$ hab.day; in cities between 500,000 and 
2 million this average comes to $0.74 \mathrm{Kg}$ / hab.day, and medium and small cities with fewer than 500 000 inhabitants the average is $0.55 \mathrm{~kg} /$ hab.day (MONTEIRO, 2001).

In Brazil, according to the ABRELPE (Brazilian Association of Public Hygiene and Special Waste), the average total daily waste production for the year 2009 is approximately 182728 tonnes. It is believed that every Brazilian produces on average half a kilogram of garbage per day, this number varies according to the purchasing power of a given location (IBGE, 2000). Brazil produces each per year, ten times its own weight in household waste, among these, about 90 cans of drinks, two trees turned into paper, usually 107 bottles, 70 cans of food and $45 \mathrm{~kg}$ of plastic.

\subsection{CHARACTERIZATION OF MSW}

Through the physical composition of solid waste are shown the economic potential of the waste, which will subsidize the choice of the best and most appropriate method of treatment and final disposal.

The characteristics and physical composition of MSW is influenced by many factors including: number of inhabitants, purchasing power, educational level, habits and customs of the population, and seasonal weather conditions, and even changes in economic policy in the region.

Municipal solid waste has different categories of components that can be obtained from the gravimetric composition. The basic components of MSW include (PROSAB 3, 2003):

- Putrescible organic matter: food scraps, flowers, tree pruning;

- Plastic: Bags, bags, packs of soft drinks, water and milk containers, cleaning products, sponges, foam, kitchen utensils, latex, raffia bags;

- Paper and cardboard: boxes, magazines, newspapers, cards, paper, plates, notebooks, books, folders;

- Glass: cups, bottles, dishes, mirrors, containers of cleaning products, packaging of beauty products, food packaging;
- Ferrous metal: steel wool, needles, food packaging;

- Non-ferrous Metal: beverage cans, scraps of copper, lead scraps, electrical wiring;

- Wood: boxes, tables, matchsticks, caps, furniture, firewood;

- Packing long-life packaging of food products (milk, juice, pasta, creams, etc.);

- Fabrics and leather clothes, cloths, handbags, backpacks, shoes, rugs, gloves, belts;

- Chemical Contaminant: batteries, pharmaceuticals, light bulbs, insecticides, rodenticides, adhesives in general, cosmetic, glass enamel, packaging, chemicals, motor oil cans, cans with paint, pressurized containers, pens with loading, carbon paper, photographic film;

- Biological Contaminant: toilet paper, cotton buds, cotton, bandages, gauze and cloth with blood, disposable diapers, sanitary napkins, syringes, razor blades, packaging anesthetics, gloves;

- Stone, earth and ceramics flower pots, plates, construction debris, bricks, gravel, decorative stones;

- Miscellaneous: candles, soap residue and soap, charcoal, chalk, cigarette butts, corks, credit cards, crayons, metallic packaging bags, vacuum cleaner, sandpaper and other materials difficult to identify.

From the gravimetric analysis of these categories you can define the technology of packaging, storage, transportation, treatment and final disposal to solid waste.

According Vilhena (1999), before starting any project that involves solid waste, it is important to evaluate qualitatively and quantitatively the profile of solid waste generated in the municipality under study allowing better structure all stages of the project.

The municipality of Macaé has not yet received any detailed study to characterize the composition of its MSW. The data contained in the RAS for the implementation of the landfill currently in operation, were based in cities with similar socioeconomic characteristics. These data are presented in Table 1. 
Table 1 - Composition of gravity / weight percentage

\begin{tabular}{|l|c|}
\hline ITEMS & \% WEIGHT \\
\hline Paper & 27,11 \\
\hline Paperboard & 2,75 \\
\hline Plastic & 11,76 \\
\hline Glass & 4,72 \\
\hline Ferrous Metals & 2,09 \\
\hline Non-Ferrous Metals & 0,46 \\
\hline Cloth and rag & 2,03 \\
\hline Wood & 1,73 \\
\hline Leather and rubber & 1,35 \\
\hline Organic matter & 46,00 \\
\hline TOTAL & 100,0 \\
\hline
\end{tabular}

Source: RAS (2005) - Landfill Macaé

RAS in the landfill is also in the prediction of MSW generation for the city over the next 20 years. These data can be found in Table 2. However, according to Veloso et al. (2009), in interview with the administrator of the landfill, the quantity of waste received, in 2009, is 320 tons per day, a figure much higher than anticipated for the year 2009, which will eventually shortens the life of the landfill. This fact proves the urgency of further studies on the characteristics of the waste generated in the municipality, and waste management alternatives that reduce the daily amount of waste going to landfill.

Table 2 - Projection of MSW generation in the city of Macaé

\begin{tabular}{|c|c|c|}
\hline \multicolumn{2}{|c|}{ YEAR } & Daily production of MSW $(\boldsymbol{t})$ \\
\hline $\mathbf{1}$ & 2006 & 200 \\
\hline $\mathbf{2}$ & 2007 & 210 \\
\hline $\mathbf{3}$ & 2008 & 220 \\
\hline $\mathbf{4}$ & 2009 & 231 \\
\hline $\mathbf{5}$ & 2010 & 243 \\
\hline $\mathbf{6}$ & 2011 & 255 \\
\hline $\mathbf{7}$ & 2012 & 267 \\
\hline $\boldsymbol{8}$ & 2013 & 281 \\
\hline $\mathbf{9}$ & 2014 & 295 \\
\hline $\mathbf{1 0}$ & 2015 & 309 \\
\hline $\mathbf{1 1}$ & 2016 & 325 \\
\hline $\mathbf{1 2}$ & 2017 & 341 \\
\hline $\mathbf{1 3}$ & 2018 & 358 \\
\hline $\mathbf{1 4}$ & 2019 & 375 \\
\hline $\mathbf{1 5}$ & 2020 & 394 \\
\hline $\mathbf{1 6}$ & 2021 & 413 \\
\hline $\mathbf{1 7}$ & 2022 & 434 \\
\hline $\mathbf{1 8}$ & 2023 & 455 \\
\hline $\mathbf{1 9}$ & 2024 & 478 \\
\hline $\mathbf{2 0}$ & 2025 & 502 \\
\hline
\end{tabular}

Source: RAS (2005) - Landfill Macaé 


\subsection{TREATMENT AND FINAL DISPOSAL OF WASTE}

The solid waste treatment consists of a series of procedures to reduce the quantity or the pollution potential of solid waste, either by preventing waste disposal in the environment or in inadequate places, is transforming it into inert or biologically stable. The main forms waste treatment used are: recycling, incinerating, composting and landfill. Table 3 presents the main characteristics, advantages and disadvantages of each type of treatment.

Table 3 - Treatment of MSW, waste types, advantages and disadvantages

\begin{tabular}{|c|c|c|c|}
\hline Treatment & Types of Waste & Advantages & Disadvantages \\
\hline Recycling & $\begin{array}{l}\text { - Plastics; } \\
\text { - Glass; } \\
\text { - Metals; } \\
\text { - Role; } \\
\text { - Cardboard; } \\
\text { - Residues of } \\
\text { construction. }\end{array}$ & $\begin{array}{l}\text { - Reduction of natural } \\
\text { resources, energy and water; } \\
\text { - Can be profitable; } \\
\text { - Decrease the volume } \\
\text { waste; } \\
\text { - Can generate employment } \\
\text { and income, among others. }\end{array}$ & $\begin{array}{l}\text { - Some recycling processes are costly; } \\
\text { - Needs market accepting materials } \\
\text { recycle; }\end{array}$ \\
\hline Composting & $\begin{array}{l}\text { - Organic as the rest } \\
\text { food, vegetables and } \\
\text { fruit; } \\
\text { - Ooze stations } \\
\text { treatment sewer. }\end{array}$ & $\begin{array}{l}\text { - Reduction of waste sent to } \\
\text { landfills; } \\
\text { - Use of the compound in } \\
\text { agriculture, gardens, etc.; } \\
\text { - Can be done in own } \\
\text { residence. }\end{array}$ & $\begin{array}{l}\text { - There may not be consumer market } \\
\text { for the compound; } \\
\text { - There may be an emanation } \\
\text { offensive odors; } \\
\text { - When unmonitored, the compound } \\
\text { can promote risk to human health, } \\
\text { animals and plants. }\end{array}$ \\
\hline Incineration & $\begin{array}{l}\text { - Hazardous waste } \\
\text { as acids, oils, } \\
\text { chemical materials, } \\
\text { etc.. } \\
\text { - Waste Services } \\
\text { health. } \\
\end{array}$ & $\begin{array}{l}\text { - Decreased considerably } \\
\text { volume and weight of the } \\
\text { waste; } \\
\text { - Increasing life landfill; }\end{array}$ & $\begin{array}{l}\text { Risks of atmospheric pollution; } \\
\text { - High cost of installation and } \\
\text { operation }\end{array}$ \\
\hline Landfill & $\begin{array}{l}\text { - Any type of } \\
\text { residuals, except of } \\
\text { radioactive. }\end{array}$ & $\begin{array}{l}\text { - Can be used most waste } \\
\text { solids; } \\
\text { - Holds the one period, } \\
\text { determined, large waste } \\
\text { volumes. }\end{array}$ & $\begin{array}{l}\text { - Demand great areas for your } \\
\text { installation; } \\
\text { - By-products generated, and biogas } \\
\text { leakage is highly polluting deserving } \\
\text { treatment often expensive. }\end{array}$ \\
\hline
\end{tabular}

Source: SNSA, 2007

The recovery of waste generated can provide many benefits not only from an environmental standpoint but also from an economic standpoint, since such solutions are both attractive in reducing transport costs and the legal provision of the landfill and in reducing overall costs of raw materials. The selection of treatment methods and final disposition should consider technical factors, legal and financial.

\subsection{SORTING AND COMPOSTING}

Composting is a biological process of decomposition via aerobic oxidation, which turns organic waste into a stable compound with different properties and characteristics of the material that caused it. Composting is usually performed in open areas where the waste is disposed in the hills of conical shape, called compost heaps. Generally 
speaking, is a biodegradation process for treating organic matter in solid waste. It is characterized by the production of $\mathrm{CO}_{2}$, water, and by releasing minerals and formation of stable organic matter (FERNANDES E SILVA, 1999). The compost produced can be used as an agricultural input, odor pleasant and free of pathogenic organisms.

Organic wastes from human activities, animal waste, leftover agriculture and commercial and industrial establishments, with a high degree of biodegradability, can be designed to composting plants, where some potential risks of these wastes are practically eliminated, such as odors, pathogen contamination and occupation of large areas of provision. The physico-chemical and biological organic waste are very diverse. The quantity and quality vary with the origin of the waste so it is necessary to know the characteristics of each residue, for decision making regarding the most appropriate technology for recycling of organic matter.

Units Recycling and composting help to reduce the total volume of trash, but still wastes are generated in the URC, which should take appropriate destination.

Earlier studies by Nimermmark and Hogland (1998) show that over $75 \%$ of household solid waste are biologically degradable and can be used to produce compost. Even after the source separation of the fraction of paper, about $55-60 \%$ of other household organic solid waste is biologically degradable.

According to D'Almeida (2000) about the economic impacts in the Brazilian context, the compost is very important, since about $50 \%$ of municipal waste consists of organic material. The main benefits of composting in the economic realm are: reductions in investments for the installation of landfill caused by the decreasing amount of solid waste, agricultural use of organic matter, recycling of nutrients to the soil reducing the costs of agricultural production, the economics of effluent treatment.

According to Figueiredo (2001), the environmental impacts of composting are on the reduction of solid organic wastes of animal or plant that no longer generate gases and odors, leachate, attract animal vectors such as flies, rats and roaches start to live, feed and proliferate on the organic debris and are typically vectors of human diseases such as typhus, leptospirosis, plague, childhood diarrhea and other equally dangerous. By com- posting organic waste is broken down, making available the nutrients to plants.

According to Wagner (1998), the social impacts involve the population that is increasingly aware of its power and duty to separate their garbage, thus contributing more actively with environmental programs and the collection of organic waste for composting, reducing the reprehensible practice of scavenging waste into streets, avenues, markets, fairs and even in the dumps, held by men, women and children who live in subhuman conditions in these areas of evictions, contact contaminated materials and dangerous case of toxic waste and medical waste.

\section{METHODOLOGY}

\subsection{GRAVIMETRIC ANALYSIS OF MSW}

Interview with experts of main knowledge areas concerning the topic. Such as the person responsible for part of the county solid waste, the landfill's manager, a representative part of garbage collectors, a statistician, about what the best method for the characterization of the garbage in the city.

3.2. Visits to the sorting and composting plants in operation in Rio de Janeiro, checking operation, materials used, layout of facilities, and interviewing those responsible for monitoring plants of the main difficulties of the processes and facilities used.

3.3. Analysis and processing of data obtained in the analysis of gravimetric composition and technical visits.

3.4. Study the economic feasibility of deploying initiatives based on the work of Miller et al. (2001). This study considers the following steps:

- Investments that include environmental licensing works for the installation, purchase of machinery and equipment and capital expenditures;

- Costs of personnel, depreciation of equipment, operating expenses and maintenance, energy costs, costs of spare parts, machinery and equipment and maintenance expenses and equipment;

- Revenue: direct, environmental and social issues. 


\section{REFERENCES}

ASSOCIAÇÃO BRASILEIRA DE NORMAS TÉCNICAS. BRAZILIAN ASSOCIATION OF TECHNICAL STANDARDS. NBR-10004: Resíduos sólidos - Classificação. Rio de Janeiro, 2004. NBR-10004: Solid waste - Classification. Rio de Janeiro, 2004.

D'ALMEIDA, MLO; VILHENA, A. Lixo Municipal: manual de gerenciamento integrado. D'Almeida, MLO; VILHENA, A. Municipal Waste: Integrated management manual. $2^{\circ} \mathrm{ed}$. Ed 2nd. São Paulo: IPT/CEMPRE, 370p. São Paulo: IPT / CEMPRE, 370p. 2000. In 2000.

FEEMA. Diretriz de Destinação de Resíduos. FEEMA. Guideline for Disposal of Waste. DZ.1311.R-4. DZ.1311.R-4. 1994. 1994. Disponível em http://200.20.42.68/meioambiente/arquivos/textos/textos/Classe300/DZ\%20 \%20DIRETRIZ/DOC-796/DZ-1311.R-4. doc>. Acesso em: 03/06/2010. Available in http://200.20.42.68/meioambiente/arquivos/ textos/textos/Classe300/DZ\% 20\% 20DIRETRIZ/DOC-796/DZ-1311.R-4.doc>. Accessed: 03/06/2010.

FERNANDES, F., SILVA, SMCP 1999. Manual Prático para Compostagem de Biossólidos. FERNANDES, F., SILVA, SMCP 1999. Practical Handbook of Composting for Biosolids. Rio de Janeiro: ABES. Rio de Janeiro: ABES.

FIGUEIREDO, PJ. M. A Sociedade do lixo: Os resíduos, a questão energética ea crise ambiental. FIGUEIREDO, PJ. M. The Society of Garbage: Waste, energy issues and the environmental crisis. Editora Unimep, 1a. Publisher Unimep, first. Ed., Piracicaba, 1994. Ed, Piracicaba, 1994.

JAMES, B. Lixo e Reciclagem. São Paulo, Scipione, 1997. JAMES B. Garbage and Recycling. São Paulo, Scipione, 1997. 43p. 43p.

MONTEIRO, JH et al. Manual de Gerenciamento Integrado de Resíduos Sólidos. MONTEIRO, JH et al. Manual Integrated Management of Solid Waste. Instituto Brasileiro do Meio Ambiente (IBAM). Brazilian Institute of
Environment (IBAMA). 15a edição, 2001, 200p. 15th edition, 2001, 200p.

Nimmermark, S. Nimmermark, S. and W. and W. Hogland. Hogland. 1998. Composting with a vertical compost reactor. Report 108, Kalmar University, (In Swedish), 92 pp. 1998. Composting compost with a vertical reactor. Report 108 , Kalmar University, (In Swedish), 92 pp.

PEREIRA NETO. Quanto vale nosso lixo. Viçosa-MG. PEREIRA NETO. How much is our garbage. Viçosa-MG. Projeto Verde Vale IEF/UNICEF, 70p. Project Green Valley - IEF / UNICEF, 70p. 1999. 1999.

RELATÓRIO AMBIENTAL SIMPLIFICADO (RAS), Novo Aterro Sanitário de Macaé-RJ. Construtora Zadar LTDA. SIMPLIFIED ENVIRONMENTAL REPORT (SAR), New Landfill Macaé. Zadar Construction LTD. Vol I. Vol I. Outubro de 2005 October 2005

SNSA, Resíduos sólidos: plano de gestão de resíduos sólidos urbanos: guia do profissional em treinamento: nível 2 / Secretaria Nacional de Saneamento Ambiental (org.). SNSA, solid wastes: management plan for solid waste: a guide to professional training: level 2 / National Secretariat of Environmental Sanitation (ed.). - Belo Horizonte: ReCESA, 2007. - Belo Horizonte: recessive, 2007.

VELOSO, A.; TUDESCO, D.; TAVARES, H.; DINIZ, L.; DIAS, MV; FAUSTINO, M.; MARIANO, R. Levantamento e Avaliação dos Aterros dos Municípios da Bacia Hidrográfica VIII. VELOSO, A.; TUDESCO, D.; TAVARES, H.; DINIZ, L., DIAS, MV; FAUSTINO, M.; MARIANO, R. Collection and Evaluation of the Municipal Landfill Basin VII. In. II Fórum Ambiental Alberto Ribeiro Lamego, Rio de Janeiro, 2009. In. II Environmental Forum Alberto Ribeiro Lamego, Texas, 2009.

VILHENA, A. Guia da Coleta Seletiva de Lixo. VILHENA, A. Guide to Selective Garbage Collection. São Paulo, CEMPRE - Compromisso Empresarial para Reciclagem, 1999, p. São Paulo, CEMPRE - Corporate Commitment to Recycling, 1999, p. 84.84. 
WAGNER, DMK, Educação Ambiental para o Cidadão. In: Simpósio Sobre a Reciclagem de Lixo Urbano para fins Industriais e Agrícolas, Belém, 1998. WAGNER, DMK, Environmental Education for Citizens. In: Symposium on Recy- cling Waste for Urban and Industrial Agriculture, Bethlehem, 1998. Anais: Belém-PA, Embrapa Amazônia Ocidental, 2000, p. Anais: Belém, Brazil, Embrapa Western Amazon, 2000, p. 157-164. 